\title{
Mass Immigration, Free Trade, and the Forgotten American Worker
}

\author{
Vernon M. Briggs, Jr.
}

If continued mass immigration and the pursuit of free trade result in undermining the nation's trade union movement and its labor-protection laws, then the price is too high. It must also be considered exorbitant if these policies continue to help reduce American workers' living standards and widen income inequality within the nation.

There have been two discretionary changes in U.S. economic policies since the mid-1960s that have caused fundamental changes to occur in the workforce of the United States.

The first, affecting supply conditions, has been the accidental revival of the phenomenon of mass immigration from out of the nation's pre-industrial past by inadvertent changes in its immigration policies. Mass immigration had been the original means by which the United States acquired and built its urban labor force during the 19th and early 20th centuries. That era came to an end in 1914. It was due, initially, to the events associated with World War I and, subsequently, to legislation passed in the 1920s. Only the year before-in 1913 - the revolutionary concept of assembly-line production had been introduced in the United States. This dramatic advance in technology launched the nation into an era of mass production and rapid industrialization, which have characterized its economic development ever since. From 1914 until the late 1960s, immigration declined steadilyin terms of its effects on the size and composition of the American workforce and of its significance to the U.S. economy.

The second change, affecting demand conditions, has been the adoption of free-trade principles as the basis for the conduct of the nation's international trade. Until the 1960s, the United States had never adhered to such practices. The domestic economy had been built behind high protective tariff walls for almost 200 years. There was no previous experience in U.S. history to demonstrate what might actually happen were it to follow this policy course. There was only the rhetoric of free-market advocates to describe what might happen in a setting based on idealized assumptions about how competitive markets theoretically operate.

Theoretically, the benefits of free trade are based on the premise that its pursuit will cause income distribution changes to occur within each trading nation. But, as Lester Thurow has poignantly written: ". . average incomes will go up with free trade, but there will be millions of losers in each country. . . The theory simply maintains that the losses of the losers will simply be smaller than the winnings of the winners." The losers, in the contemporary case of the United States, are those unskilled and poorly educated workers who, under protectionism, were able to secure jobs - sometimes even with high wages. Disproportionately, they are workers from minority groups. Those in the manufacturing sector have been especially vulnerable. The winners are high-skilled and bettereducated workers who often are employed in service industries. Thurow also notes that ". . the theory assumes that the winners will compensate the losers so that everyone in each country has an incentive to move to free trade but in fact such compensation is almost never paid." With the exception of a few provisions for retraining some displaced workers, there are no compensation provisions in any of the new trade policies adopted by the United States.

\section{THE $1960 \mathrm{~s}$}

In the 1960 s, at the time the initial steps were taken to alter the prevailing immigration and trade policies, there was no recognition of any relationship between the two policy initiatives. The nation still basked in the unparalleled benefits of the economic prosperity of the post-World War II period. Real income was rising sharply and income inequality was being reduced. Looking back, it is clear that no one anticipated what was about to happen 
to the American workers as the direct result of those discretionary actions taken by their own federal government in both of these key policy areas.

While elements of immigration policy in the early 1960s were topics of continuing controversy, the attention of reformers was focused primarily on the means of selection, not on the level of immigration. The most contentious issues in immigration policy debates at the time centered upon efforts to terminate the Mexican labor program (the infamous "bracer program"), and on the controversy over the right of border commuters (i.e., "greencarders") to work in the United States, even though they continued to live in Mexico.

Indeed, the significance of immigration in American life and the American economy had been declining for more than forty years. The number of foreign-born persons in the United States in 1970 (9.6 million people) was lower in absolute terms than at any previous (or subsequent) time in the 20th century. Moreover, its percentage of the total population (4.6 percent) in 1970 was also at a level lower than at any previous or subsequent time in U.S. history. With the initial wave of the "baby boom" generation just reaching the primary labor-market entry age of eighteen years in 1964 (a phenomenon that would continue to supply record numbers of labor-force entrants for the next sixteen years), there was no prospect of a labor shortage on the nation's horizon.

The goals of the civil rights movement came to fruition in the 1960s. Its activities culminated in the passage of the Civil Rights Act of 1964, with its historic equal employment opportunity provisions. With the adoption of this landmark antidiscrimination legislation, and with the active pursuit of an expansionary fiscal policy (i.e., the broadbased tax cuts that also had been enacted in 1964), we were confident we would reduce unemployment. The adoption of a broad array of inclusive human-resource development programs by the Johnson Administration began to prepare black workers for the jobs the new "Great Society" was about to create. Tight labor-market conditions would force employers to hire blacks - now protected by equal opportunity laws. The newly enacted human resource programs would assist them to become qualified to compete for such job openings.

When the Immigration Act of 1965 was passed, it too was seen as part of this broad-based effort to eliminate the last vestiges of overt discrimination from American public policy. It was also seen as an integral part of the nation's civil rights agenda. Immigration reformers attacked the explicit ethnocentrism of the national origins admission system, which had been put in place in 1924 and had continued since that time. Certainly, there was no intention to increase the level of immigration. The reformers sought only to eliminate the overt discrimination that was embodied in the extant legislation. Indeed, the floor manager in the Senate for the Immigration Act of 1965, Edward Kennedy (D-Mass.), stated unequivocally during the final floor debate that "this bill is not concerned with increasing immigration to this country; nor will it lower any of the high standards we apply in selection of immigrants." Subsequent events, however, have shown that his expectations were wrong on both counts. The 1990 Census revealed that the foreign-born population (which totaled 19.7 million persons as officially measured, but which undoubtedly missed many more who had entered illegally) had more than doubled the level reported only twenty years earlier in the 1970 Census. Moreover, the skills and education of those immigrants entering since 1970 have been found to be considerably below those of earlier waves of immigrants at similar stages of assimilation. The incidences of poverty, unemployment, and welfare dependency among them were also higher than was true of earlier immigrants. And their labor-force participation rate was lower than earlier waves. Another era of mass immigration to the United States had commenced and, like its predecessor, it mainly involved people who lacked human-capital endowments. It was the low-skilled segment of the U.S. labor force in general, and the minority work force in particular, who bore the brunt of their competition.

With respect to trade policy, we seem to have forgotten that the economy of the United States was not built on the basis of "free trade," or on anything else even barely resembling that concept. In fact, the nation's rise to world economic prominence was based precisely on the fact that it did not depend upon its control of foreign markets. Rather, it produced its own goods for its vast home market. Foreign competition was largely prohibited. Tariffs were first enacted in 1789 against certain foreign imports as a means to provide revenue for the newly 
established nation. Alexander Hamilton, the first U.S. Secretary of the Treasury, had proposed an even more extensive system of tariffs to protect the nation's infant industries. Initially, his advice went unheeded. But during the War of 1812 with Great Britain, U.S. industry flourished when foreign trade was cut off due to a British naval blockade of the coastline. Following the American victory in that war, business interests gained sufficient political control to have protective tariff legislation imposed on most imported goods. Their efforts were joined by western farmers, who also favored protection from foreign competition for their agricultural products. Thus, the Tariff Act of 1816 was adopted. It was the first purely protective tariff legislation in U.S. history. But it was far from the last.

The Tariff Act of 1824 expanded the coverage of goods and raised the rates. Similar steps were taken again in 1832. There were some downward revisions in the rates in 1833. But they were raised and the coverage was expanded again by the Tariff Act of 1842. In part, the Civil War itself was fought over the tariff issue. The Whig Party of the North (later to become the Republican Party) strongly favored tariffs. The other party (called Republicans at the time, but later to become the Democratic Party) was split over the issue. Members from the South were opposed to tariffs, while members from the North and West were in favor of tariffs. The subsequent defeat of the South in the war not only meant the end of slavery, but the end of the opposition to tariffs for many decades to come.

Tariffs remained high into the 1880 s. During the election of 1888, in fact, the subject was the major issue of the presidential campaign. The Republicans won. President Benjamin Harrison led Congress to enact the McKinley Tariff Act of 1890. It raised tariffs to the highest levels in U.S. history. It also extended coverage to goods never before covered. A substantial reaction to this legislation ensued. But by the time Congress finished with it, the "reform" legislation-the Wilson-Gorman Tariff Act of 1894-actually expanded the existing protections. The presidential election of 1896 also centered on tariff issues. William McKinley's defeat of William Jennings Bryan meant another victory for tariff supporters. Subsequently, the Dingley Tariff Act of 1897 raised tariffs again to new heights. There were efforts to modify some of the tariffs in 1909, but they resulted in the enactment of only minor revisions. President Woodrow Wilson (who was elected partly because the Republican Party was split over tariff policy in the presidential campaign of 1912) succeeded in gaining passage of the Underwood Tariff Act of 1913. It significantly lowered existing tariff rates. These reductions, however, had a short life. Not only did World War I inhibit trade, but tariffs were again raised (following the war) by the Emergency Tariff Act of 1921. And they were raised again by the Fordney-McCumber Act of 1924.

When the depression hit the U.S. economy in 1929, Congress responded by passing the infamous SmootHawley Tariff Act of 1930. It raised U.S. tariffs to historic heights. The significance of the passage of the SmootHawley Act, however, was not that it involved the imposition of tariffs (as was mischievously suggested by Vice President Al Gore in his 1993 television debate with Ross Perot over the efficacy of NAFTA), but that it raised tariffs just another notch above their already high levels.

It was with the election of President Franklin Roosevelt in 1932 that the United States began the process of altering its tariff posture. A new position was established. It involved the principle of reciprocal tariff reductions that would be determined through bilateral negotiations between the United States and other nations on an individual basis. You cut your tariffs on specific goods, and we will cut ours. But before any significant changes could occur, World War II interrupted the process. During the war years, foreign trade came to a virtual halt. But the productive capabilities of the United States were dramatically increased. Moreover, the productive capabilities of all the other major industrial nations of the world were destroyed during the war. The United States emerged from the war as the leading industrial power on the planet. In 1950, it accounted for 50 percent of the world's total production of goods and services.

From this position of strength and dominance, the United States slowly began abandoning its protectionist tradition. It was to its economic advantage to do so. The United States was instrumental in the adoption in 1947 of the General Agreement on Tariffs and Trade (GATT). Forty signatory nations (including all of the industrial powers 
of the noncommunist world) pledged to reduce the tariff barriers to world trade. At the time, it was understood that a parallel agreement among GATT members setting minimum labor standards for wages and working conditions would soon be negotiated. It would assure the creation of minimum labor standards which would establish criteria for the conduct of the new international trading arrangements. But to this date, the international labor standards agreement has yet to emerge.

It was not until the early 1960 s that the actual process of tariff reduction began. In 1962, the United States enacted the Trade Expansion Act. It permitted President John F. Kennedy to enter into negotiations that could lead to tariff reductions of up to 50 percent of their existing levels. It also authorized the President to participate in the GATT negotiations - to be held in Geneva in 1964. These talks were subsequently called the "Kennedy Round"-in honor of the president, who had been assassinated the year before.

In the early 1970 s, this process suffered a brief setback when President Richard Nixon imposed a 10percent surtax on all imported manufactured goods to the United States. But in 1980, the election of President Ronald Reagan brought into office a Republican president who was committed to reducing government involvement in free-market operations. In contrast to his party's heritage, he was a strong advocate of free trade. Further GATT negotiations began in 1986. They covered a broader range of agreements in such areas as copyrights, software, investment services, and the ever-thorny issue of agricultural subsidies. These talks - known as the "Uruguay Round"- ultimately reached final agreement among the 107 signatory nations in late 1993, and were formally signed in Marrakech, Morocco in April 1994. It was also in 1993 when the United States signed NAFTA with Canada and Mexico. NAFTA seeks ultimately to eliminate tariffs on trade among these three nations.

\section{TRADE AND IMMIGRATION POLICY DEVELOPMENT}

With regard to trade and immigration policy development, therefore, the United States has passed through three distinct periods. Each deserves a brief review:

- Mass Immigration and High Tariffs. The first period commences at the time when the United States actually began to function as an independent nation in 1788. It lasts roughly to when World War I broke out in Europe in 1914. During that time, as discussed earlier, the United States had the consistent experience of using tariffs to protect its business and agricultural enterprises. It was a period of generally escalated tariff rates and broadened coverages. But in the labor market, it was a period of virtually unrestricted immigration. Thus, the labor market functioned under conditions of nearly unlimited competition, while the product market was comprehensively sheltered from most foreign imports. The net result was the stimulation of domestic competition.

During this era, conditions for workers were uniformly deplorable. "Sweatshops" flourished. Wages were low. Long work days were standard. Unsanitary, unhealthy, and unsafe working conditions were virtually universal. Child labor was commonplace. Employment discrimination was widespread. It was also a period that witnessed frequent spells of cyclical unemployment without any income maintenance provisions for those who lost their jobs. The few efforts to establish trade unionism during this era were generally unsuccessful—except in a few skilled crafts, and in the railroad industry. Even these unions had to struggle to survive. Under these conditions, business interests generally prospered and dramatically expanded in scale.

- Low Immigration and High Tariffs. The second stage extended roughly from 1914 to the mid-1960s. It was the period in which mass immigration essentially came to a halt. But tariffs continued to be broad in coverage, to rise (through 1933), and to remain high.

Essentially, the nation's initial experience with mass immigration ended in 1914. Would-be emigrants from Europe could not leave. Immigration from Asia had been largely restricted by exclusionary laws enacted in 1882 against the Chinese and by a "gentleman's agreement" with Japan. But Asian immigration from the Philippines (which was a U.S. colony from 1898 until 1946) continued, until it too was sharply restricted in 1934. When World 
War I ended in 1918, immigration pressures from Europe showed signs of returning to their prewar levels. This process, however, was quickly halted by temporary legislation in 1921 that became permanent three years later with the passage of the Immigration Act of 1924. It was also called the National Origins Act, due to the discriminatory admissions system it enacted favoring immigrants from Western and Northern Europe, but disfavoring or prohibiting immigration from everywhere else in the Eastern Hemisphere. It also imposed a ceiling on Eastern Hemisphere immigration for the first time.

With the exception of the depression decade of the 1930s, however, the United States experienced the most prosperous period in its economic history during these years. Real income soared in the $1920 \mathrm{~s}$, and again throughout most of the post-World War II period, through the decade of the 1960s. Over this period, the United States created a variety of high-wage jobs that became the envy of the world. In the process, the nation developed a massive domestic market - especially for expensive but technologically advanced goods and services produced by its highly heterogeneous industrial structure.

It was also during this time that the nation began to enact a broad range of worker-protection laws and social-insurance systems to remove some of the harshness of working and living in a competitive society. These ranged from laws dealing with minimum wages, maximum hours, child-labor bans, unemployment compensation, food stamps, Aid For Dependent Children, Social Security, Medicare, and occupational health and safety. It also included federal government support for the establishment of a system of collective bargaining to resolve workplace disputes between labor and management. Membership in trade unions soared to include about one of every three workers in the 1950s. The initial steps to end overt discrimination were also enacted in this era.

With the exception of the depression years, this era (for the most part) was the most prosperous in U.S. history. Not only did production levels soar, but employment levels, living standards, and business profits did as well. The disparity in the distribution of income among American families also was reduced.

- Mass Immigration and Low Tariffs. The contemporary era began in the mid-1960s. It has been marked by the resumption of mass immigration and a sustained effort to reduce tariff rates and coverages. Putting aside the many platitudes associated with immigration and free trade, the fact is that the nation has now entered into uncharted waters. So far, if the standard for judgment is the impact on the American worker, the signs are not encouraging

There has been a marked upward trend in the nation's unemployment rate since the mid-1960s. The unemployment rates of the mid-1960s were in the mid-3 percent range. In every succeeding period of prosperity since that decade, the unemployment rate has tended to be higher than in the preceding prosperity period. The annual unemployment rate has not been below 5 percent since 1970. Those worst affected by this secular trend of gradually rising unemployment have been the less-skilled workers. And their ranks are disproportionately composed of minorities, youth, and women.

But even worse have been the effects of what the macroeconomist Wallace Peterson has identified as declining real family incomes. This downward trend began in 1973, and has continued to this day. Studies that have focused on trends of real earnings show that they too have been falling since 1973. But the losses have been the greatest for those with the least education. The U.S. Bureau of the Census, for example, reported in 1991 that white males aged 25 to 34 , with less than a high school diploma, experienced a 42 percent decrease in real earnings from levels that existed in 1973. High school graduates sustained a 31 percent decrease in their earnings. Those with some college have experienced a 21 percent decline in earnings. Even college graduates have seen a 14 percent decrease in real earnings. For women and nonwhites, the declines have been even more pronounced. Although studies that focus specifically on the effects of immigration on earnings are sparse, there is specific evidence that the immigrants of the 1980s have exerted a negative influence on the wages of native-born workers who have low skills. 
The nation's poverty-stricken population has increased from 31.7 million in 1988 to 36.9 million in 1993. The percentage of Americans living in poverty in 1993 (14.5 percent) was the highest recorded for any one year since 1983, when it was 15.2 percent. In other words, while the percentage of the population living in poverty declined slightly after 1983, it has been rising again in the 1990s. In fact, the data for 1993 reveal that poverty increased three times faster that year than did the overall population.

Given these trends, it should come as no surprise that the distribution of family income in the nation became distinctly more unequal during the decade of the 1980s. The lowest one-fifth of all families in the United States saw their share of all income decline from 5.2 percent to 4.6 percent between 1979 and 1989. The top onefifth of all families saw their share of all income increase from 41.5 percent to 44.3 percent. The top 5 percent of all families saw their share increased from 15.3 to 17.4 percent during this period. As for the state of trade union members, their numbers have been contracting since the 1960s. By 1992, fewer than 16 percent of the labor force were union members-about one-half the percentage of the 1950s.

Even worse has been the increase in reported violations of the nation's worker-protection laws in the 1980s and early 1990s. Accounts of the revival of child-labor violations, the return of "sweatshops," and extensive fairlabor-standards abuses abound in urban areas - especially in those communities inundated by the recent waves of immigrants, who are themselves often the victims of such exploitation. It is also clear that the economic status of urban blacks is deteriorating in the wake of the onslaught of immigrant competitors and the rapid erosion of the urban job base - due, in part, to the effects of free-trade practices.

\section{IMPERATIVES FOR POLICY CHANGE}

Certainly, there are other factors that cause the aforementioned conditions. The differential employment impact of computer-based technology would rank alongside the adverse effects of the new trade and immigration policies. There are also the demographic effects having to do with the "baby boom generation" and the women's movement. They both have contributed to the unprecedented increases in the labor force we have witnessed during this period. Defense cutbacks have also caused dislocation effects - the result of the unexpected end of the Cold War in 1991 and of shifting consumer spending preferences toward services. But this is precisely the point. The labor market is in a state of rapid transformation with regard to the industrial, occupational, and geographic changes in employment patterns. Many of the causative influences are beyond the capacity of public policies to control. Policymakers can only try to respond in effective and compassionate ways. But immigration and trade policies are purely discretionary actions. In this period of rapid economic change, they both should be shaped to serve the national economic interest. Neither can be said to be so shaped today.

The preeminent domestic economic problem facing the United States in the 1990s is what to do with the rapidly increasing surplus of unskilled and poorly educated job-seekers in an era when low-skilled jobs are rapidly disappearing. Pending welfare reform proposals by the Clinton Administration-for example, to force more than two million adult welfare recipients to go to work - cannot possibly be taken seriously unless something is done to stop the inflow of unskilled, poorly educated, and largely non-English-speaking immigrants (especially those who enter illegally) into low-skilled urban labor markets. And we must reduce the incentives for firms that hire significant numbers of low-skilled workers to move abroad or shut their doors, because they cannot compete with foreign imports.

Indeed, the plight of low-skilled workers in this country is so ominous that I deem three public policy proposals mandatory, if we seriously care about the welfare of these workers:

- First, the nation's legal immigration system must be amended to prohibit the admission into the United States of unskilled adult workers as immigrants or nonimmigrants, regardless of the admission category. The only exception would be for spouses. 
- Second, it is mandatory that steps be taken to tighten the enforcement of the nation's immigration laws with respect to illegal entry and the abuse of the political asylum system by economic refugees.

- Third, it is essential that public policy identify those occupations (especially in the goods-producing industries) that continue to employ low-skilled workers (e.g., in garment manufacturing and in agriculture). We need to impose significant tariffs on foreign imports into these industries as a way to prolong the ability of the U.S. firms who produce similar goods to stay in business.

If anyone has better ideas, they desperately need to be brought forth into the arena of public debate. But this nation cannot rely on the standard homilies of free market advocates that, somehow, the market will adjust to these radically new employment patterns. To the degree that it does, it will do so with extreme human cruelty and will increase the likelihood of worsening social tensions.

The mass-immigration and free-trade movements are part and parcel of a broader movement toward a laissez-faire economic environment. Its goal is to reduce the discretionary role of government to influence economic outcomes, leaving those outcomes to be caused by invisible market forces. But market forces have traditionally manifested little concern for worker rights, human welfare, or environmental protection. These forces are insensitive to the difficulties often experienced by individuals, their families, or their communities to adjust to such unfettered decisions.

Under the free-market paradigm, markets are assumed to be efficient. Hence, any interference in their operation is alleged to be a departure from perfection - no matter how humane, compassionate, or wise such interference might seem to be. But if one starts from the opposite assumption-that markets are not inherently efficient-interventions in an imperfect world can improve the conditions of life and welfare of both individuals and nations.

We require an immigration policy that is flexible in the number of people it allows to enter the United States legally each year. Likewise, one that admits people primarily on the basis of the human capital endowments they bring (and that the U.S. labor market seeks) is needed. In other words, the nation's immigration policy ought to be accountable for its economic consequences. The present system is not. It must be a policy that is firm in the certainty that its terms will be enforced against illegal entry and refugee abuse. It must also contain provisions that allow U.S. employers to hire nonimmigrant foreign nationals in only the most extreme labor-shortage situations.

In addition, the trade policy of the United States must be required to meet the same standard. Its provisions must serve national interests, and not special interests. The fundamental rationale for trade between nations should be to raise real living standards. It should not be to contribute to an erosion of existing work standards, or to a loss of employment opportunities. Neither should it allow pollution of any nation's environment, or provide a vehicle for employers in advanced nations to exploit workers in less-developed countries for competitive gain.

Currently, neither U.S. immigration nor trade policies can be said to meet the standard of being designed to raise the real living standards of American workers. Indeed, in their present forms, they both represent the opposite of that goal. Simply stated, the welfare of workers is not a priority of either. Only the private financial interests of influential sectors of the business community are being served by the present policies.

It is past time for working people and those who empathize with their welfare to see to it that both of these discretionary policies be changed from their present forms. If continued mass immigration and the pursuit of free trade result in undermining the nation's trade union movement and its labor-protection laws, then the price is too high. It must also be considered exorbitant, if these policies continue to help reduce American workers' living standards and widen income inequality within the nation. 